\title{
INCONSISTENCY IN THE USE OF LEGAL CONCEPTS IN THE REGULATIONS OF LAND ACQUISITION IN INDONESIA
}

\author{
Agus Sekarmadji \\ Administrative Departement, \\ Faculty of Law, \\ Airlanga University \\ agussekarmadji_unair@yahoo.com \\ Faizal Kurniawan \\ Private Law Departement, Faculty \\ of Law, \\ Airlanga University \\ faizal@fh.unair.ac.id
}

\author{
Rizky Amalia \\ Private Law Departement, Faculty \\ of Law, \\ Airlanga University ria \\ riasetyawati@fh.uniar.ac.id \\ Ria Setyawati (Author) \\ Private Law Departement, Faculty \\ of Law, \\ Airlanga University ria \\ riasetyawati@fh.uniar.ac.id
}

Abstract--- In the context of development, an acquisition of land rights is required. Within the regulations concerning the acquisition of land rights, it is found an inconsistency in the use of legal concepts. Referring to such inconsistency, therefore, it is urgent to perform diligent research on which legal concept is appropriate and correct to be employed. The research is necessary to bring the legal certainty. Regulations concerning the acquisition of land rights must clear and consistent in employing concepts. The application of such concept is based on the relationship between the state and the land. On the basis of such relationship, there is land which identified as "land state" and land which identified as "land with title right". Upon land state, the acquisition can be processed firstly through waving rights and continued by filing the proposal of acquiring the rights. Upon the land with title right, the acquisition can be pursued by transferring the rights by means of purchase or exchange transaction.

Key Words: Land Acquisition, Inconsistency, Legal Concept.

\section{INTRODUCTION}

Land acquisition is inevitable in development activities. Viewed from the laws and regulations perspective, especially from the Basic Agrarian Law (BAL), actually, there is a distinction between provisions regulating the acquisition of land right in the public interest and provisions governing the acquisition of land right for other than public interest. In relation to the acquisition of land in the public interest, there are two important articles, namely Article 18 and Article 6. Article 18 states that for the public interest, including the interest of the nation as well as the common interest of the people, land rights may be revoked by giving adequate compensation in the manner set forth in 
the Law. Pursuant to Article 18 of the law, Law No. 20 of 1961 on Expropriation of Land and the Properties Thereon was issued. If understood, the provisions under Article 18 of the BAL and Law No. 20 of 1961 only concern the procurement of land in the public interest. Hence, it can be seen that in order to carry out development for the public interest, a person or legal entity holding the titles must be willing to release their land. This is in accordance with the provision set forth in Article 6 of BAL stating that all land rights have a social function. Land use must be inline with the circumstances and nature of the title so that it benefits both the owner's well-being and happiness, and the community and the state. This does not mean that individual rights will be overridden entirely by the public interest. Therefore, persons or legal entities whose land is affected by development projects in the public interest are entitled to adequate compensation. Consequently, there will be a balance between private interest and public interest so that the ultimate goal of prosperity, justice, and happiness for all people hopefully could be achieved.

Regulations on land procurement in the public interest have undergone various changes. The following are the various regulations: Minister of Home Affairs Regulation (Permendagri) No. 15 of 1975 on the Provisions on the Procedures for Land Acquisition; Presidential Decree No. 55 of 1993 on Land Acquisition for Development Activities in the Public Interest which is revised by Presidential Decree No. 36 of 2005 on Land Procurement for the Implementation of
Development in the Public Interest which was later amended by Presidential Decree No. 65 of 2006; and Law No. 2 of 2012 on Land Procurement for Development in the Public Interest. These various changes are expected to increase respect for land rights of individuals. For example, Permendagri No. 15 of 1975 was revoked by Presidential Decree No. 55 of 1993 because the regulation is considered to have disrupted the stability of land market pricing.[1].

\section{Discussion}

\section{The Nature of Legal Concepts}

Satjipto Rahardjo states that a legal concept should refer to the empirical elements underlying it. A concept should also be meaningful. A noise produced by the human being but containing no message at all cannot be called as a concept.[2] Kaplan, as quoted by Satjipto Rahardjo, argued that a concept spontaneously forms a certain definition in the heads of the people who catch it, hence it is referred to as "meaningful". Next, Satjipto Rahardjo argued that a legal concept should have an empirical basis. These legal concepts will be a measure to assess and judge reality, especially human actions. On this basis alone, actually, any legal concept in itself should have an empirical relevance. Such is the relationship between concept and reality. The making of concepts or definitions enables a universal dimension to enrich the accumulated theoretical and practical knowledge because the notions can be translated into various languages as far as the languages concerned allow it.[3] Accordingly, with a definition, a concept's 
limitations are expected to be spelled out clearly. Therefore, it is necessary to have a clear concept, especially in the field of law, because it will facilitate understanding of law and could ultimately give legal certainty.

\section{II.Analysis of Legal Concepts of Land}

\section{Provision, Indirect Transfer of Title, Land}

\section{Procurement, Land Acquisition, and Land}

\section{Expropriation}

On the basis of this relationship, the state can grant land rights to both individuals and legal entities. Thus, the existing plots of land that have been owned are called the land of right, while the land on which absolutely no one has right is called state land. The term "state land" originated from the days of the Colonial Dutch. In accordance with the concept that the ruler (the Dutch East Indies Government) was the owner of land,

the Government issued a declaration known as Domein Verklaring.[4] The declaration of state ownership over land was issued as a revitalization of the feudal relationship in the past, a relationship which had been exploited by the Vereenigde Indesche Oost Compagnie (VOC) and maintained in the reign of Raffles (1811-1816), and further strengthened by domein verklaring in Agrarisch Besluit (Stb. 1870 No. 118) as an implementing regulation of the Agrarische Wet (stb. 1870 N. 55) stipulating that all the land on which nobody can prove ownership belongs to the state.[5] In practice of land laws, this domein verklaring declaration served as the legal basis for the government representing the state as the owner of all land, to grant Western land rights as set forth in the Civil Code such as the erfpacht (long lease) right and opstal (premises) right. In addition, it also served a function in proving ownership.[6]

Consequently, the domein verklaring detrimentally affected the land rights held by the people individually and collectively such as the communal title of traditional communities, because different from Western land rights, indigenous land in general has no evidence of ownership. Further, Point 1 of the General Elucidation of Government Regulation No. 8 of 1953. Domein verklaring existence was indeed very detrimental to the interest of landowners because its only benchmark was written evidence. ${ }^{[7]}$ State land ownership is put in one hand, and the agency entrusted with this is the Home Affairs Ministry. As a consequence, state land that is no longer needed or used by agencies in accordance with their duties must be returned to the Minister of Home Affairs. After the birth of the Basic Agrarian Law (BAL), the relationship between the state and lands is no longer that of ownership but control. The state's right to control includes the right to control earth, water, and space, including the natural resources contained therein.[8] According to Maria S.W. Sumarjono, with the birth of the BAL, state land in question is the land that is not covered with any right, whether it is fee simple, right to exploit, right to build, right to use on state land, right of management, communal title or a bequest. The handing over of land by the owner to 
become state land often occurs in the activities of land acquisition in which the party who needs the land cannot become a subject of land right. Similarly, the land will become state land if the right holder dies without leaving an heir. In relation to abandoned land, it is stipulated in Government Regulation No. 11 of 2010.

The right concept for obtaining land rights by applying rights on state land is the procurement of land rights (underline from the author). I say that procurement of land rights is appropriate because the object of the application is state land, meaning there is no right on it. While towards a plot of land with the title on it, transfer of title is the method. The concept of "land procurement" in Minister of Home AffarisRegulation No. 2 of 1985, Presidential Decree No. 55 of 1993 and Presidential Decree No. 36 of 2005 as amended by Presidential Decree No. 65 of 2006 and Law No. 2 of 2012 in my opinion is not quite right. Humans have never procured (i.e. created) land, as land in Indonesia has been around since time immemorial which is a gift of God Almighty. As described in Article 1 Paragraph 2 of the BAL, the whole earth, water and natural resources contained therein within the Republic of Indonesia is a gift of God Almighty. The definition of land is the earth's surface (Article 4 Paragraph 1 of the BAL). As we know "land" is a definition of a concept.[9] Meanwhile, what can be procured is the right to the land. Thus the concept of land procurement is not appropriate, while the concept of procurement of land rights is appropriate only if the process is through the application for rights towards state land.
The concept of "indirect transfer of title" as stipulated in Permendagri No. 5 of 1975 is also less than precise. The concept of "indirect transfer of title" in this regulation is not the same as expropriation.[10] In the Permendagri "indirect transfer of title" is defined as terminating the relationship between the right holder and his land by giving compensation. This definition is more appropriate to be used to define "expropriation". The activity of expropriation is one of the processes in land right acquisition. The concept of "provision of land" which is defined as every activity to obtain land for companies by giving compensation to those entitled is not quite right. In my opinion, the definition contradicts the concept. The concept of "provision" gives us the sense that no effort is required to obtain right to land because the land is already provided. But the definition mentions activities to obtain land, which certainly includes efforts and activities to obtain the right over the land. On the other hand, especially in the construction of housing complex, it seems that no land will be provided by other parties, but it is certainly preceded by efforts to obtain land rights. The concept of land expropriation may be justified in order to attempt acquisition of land right in the public interest.

\section{Comparison with Legal Concepts of Land}

\section{Acquisition in Malaysia}

As a comparison, we will discuss land acquisition in Malaysia. Regulations on land acquisition in Malaysia are set forth in the Land Acquisition Act of 1960, as revised in 1985. In 
Malaysia, land acquisition is translate as land taking. As in Indonesia, land acquisition in Malaysia stipulates that the party doing the acquisition must give compensation. Acquisition of land in Malaysia, like in Indonesia, is conducted in order to meet land needs in the implementation of development. However, in Indonesia, land acquisition in the public interest is distinguished from land acquisition for other than public interest. In Indonesia, the difference is clear when viewed from the executor of land acquisition. In Malaysia, the difference is not visible. Acquisition of land by force is carried out by the state authorities. This is as stated by $\mathrm{Hj}$. Salleh and $\mathrm{Hj}$. Buang that $\mathrm{In}$ Malaysia, only the State Authority can acquire lands compulsorily. Teo Keang Sood and Khaw Lake Tee say The compulsory acquisition of land by the State Authority.[11]

\section{Comparison with Legal Concepts of Land}

\section{Acquisition in the Netherlands}

In Dutch laws and regulations, there is a legal concept of verkrijging. This is equal to acquisition in English. From the description of Article 80 Book 3 of the NBW we know that the acquisition of rights can be grouped into two: first, the acquisition through a general entitlement, in this case, inheritance, and second, the acquisition through special entitlement consisting of transfer of rights, expiry, and expropriation.[12] From Neufeldt's statement it is clear that expropriation is used only for the public interest. Expropriation is the taking a person's land right without the consent of the owner in the public interest and the owner is given compensation. Before the expropriation procedure is done, the government attempts to acquire land rights through negotiation with the landowner. If the negotiation does not reach an agreement, expropriation procedure is applied. The main concept of Property Law is eigendom (ownership), like in France and Germany laws. Under Article 1 Book 5 of the NBW, this right is classified as "the most comprehensive right which a person can have in a property",[13] Before the NBW was enacted, expropriation (onteigening) had also been applied. The prevailing onteigening is actually based on a very high respect for the ownership right (eigendom). As stipulated in Article 570 of the BW, ownership right is the right to enjoy the benefits of property freely, and to act independently on the property with full sovereignty, insofar as it is not contrary to law or general rules defined by the authorities, and not interfere with the rights of others without reducing the possibility of expropriation in the public interest based on the provisions of law and the payment of compensation.

\section{Conclusion}

There are various concepts used in Indonesia laws and regulations, namely the concepts of land provision (penyediaan tanah), indirect transfer of title (pembebasan tanah), land procurement (pengadaan tanah), land acquisition (perolehan tanah) and expropriation (pencabutan hak atas tanah). Among the various concepts, the most appropriate is the concept of "acquisition of land rights". It is based on the relationship between 
the state and land, which is the relationship of control. On the basis of this relationship, there is land with the status of state land and land with the status of right on it. The concept of legal acquisition of land rights can be applied to both state land and land of right. Towards the plots of land that have no rights on it, land acquisition can be carried out by way of right application. While towards a plot of land with the title on it, transfer of right (conveyance) is the method. A Land whose right has been disposed of becomes state land and acquisition can be done by application for the right. The legal concept of land right acquisition is broader than the legal concept of land right procurement. Because the legal concept of land right acquisition is appropriate only if the desired land is state land rather than the land of right.

\section{BIBLIOGRAPHY}

[1] P, Parlindungan A. Komentar Atas UndangUndang Perumahan dan Pemukiman \& Undang-Undang Rumah Susun. Bandung: Mandar Maju, 1997.pp 9.

[2] Rahardjo, Satjipto. Ilmu Hukum. 6th. Bandung: PT Citra Aditya Bakti, 2006.pp 312.

[3] J.J.H, Bruggink. Refleksi Tentang Hukum. Bandung: Citra Aditya Bakti, 1999. pp 48

[4] Sumardjono, Maria S. W. Tanah Negara. Kompas, 1994.

[5] Faizah, Lilis Nur. Hak Menguasai Negara, Suatu Pendekatan Historis-Filosofis. n.d. <www.zeilla.wordpress.com>.pp 2.

[6] Harsono, Boedi. Hukum Agraria Indonesia, Sejarah Pembentukan Undang-Undang Pokok Agraria, Isi dan Pelaksanaannya. Jakarta: Djambatan, 1994.pp 43.

[7] Supriadi. Hukum Agraria. Jakarta: Sinar Grafika, 2008.pp 49.

[8] Suhaimi, Ahmad. Hak Menguasai Negara Atas Mineral Dan Batubara. (Surabaya: Grammatical Publishing, 2016) pp 87.
[9] Ramelan, Eman. Hukum Pengadaan Tanah Bagi Pembangunan Untuk Kepentingan Umum Di Indonesia. (Surabaya: Kerjasama AUP dengan LP3 UNAIR, 2014) pp 1

[10]Soimin, Sudharyo. Status Hak Dan Pembeasan Tanah. (Jakarta: Sinar Grafika, 2001) pp 72.

[11] Teo Keang Soo, Khaw Lake Tee. Land Law in Malaysia, Case, and Commentary. (Kuala Lumpur: Butterworths, 2nd edn, 1995) pp 720.

[12] Sekarmadji, Agus. Prinsip-Prinsip Hukum Perolehan Hak Atas Tanah Dalam Rangka Pembangunan Perumahan. (Surabaya: Pascasarjana Universitas Airlangga, 2010) pp 105.

[13] Chorus, Jeroen, Piet-Hein Gerver, and Ewoud Hondius. Introduction to Dutch Law. (Kluwer Law International, 2006) pp 103. 